\title{
SMAD2 Gene
}

National Cancer Institute

\section{Source}

National Cancer Institute. SMAD2 Gene. NCI Thesaurus. Code C24566.

This gene plays a role in signal transduction and repression of transcription. 